\title{
Streptomyces sparsus sp. nov., isolated from a saline and alkaline soil
}

\author{
Correspondence \\ Yi Jiang \\ jiangyikm@hotmail.com \\ Johannes F. Imhoff \\ jimhoff@ifm-geomar.de
}

\author{
Yi Jiang, ${ }^{1}$ Yan-Ru Cao, ${ }^{1,3}$ Jutta Wiese, ${ }^{2}$ Shu-Kun Tang, ${ }^{1}$ Li-Hua Xu, ${ }^{1}$ \\ Johannes F. Imhoff ${ }^{2}$ and Cheng-Lin Jiang ${ }^{1}$
${ }^{1}$ Yunnan Institute of Microbiology, Yunnan University, Kunming, Yunnan 650091, PR China
${ }^{2}$ Leibniz-Institut für Meereswissenschaften, IFM-GEOMAR, Düsternbrooker Weg 20, D-24105 Kiel, Germany
${ }^{3}$ College of Resources and Environment, Northwest A \& F University, 712100 Yangling, Shaanxi, PR China

The genus Streptomyces was proposed by Waksman \& Henrici (1943) and species of this genus are of great interest owing to their production of various natural products with considerable commercial value. In the course of screening of actinomycetes for bioactive metabolites, strain YIM $90018^{\mathrm{T}}$ was isolated from a saline and alkaline soil sample collected from Qinghai Province, China. Strain YIM $90018^{\mathrm{T}}$ was isolated on starch-casein medium with $20 \%(\mathrm{w} / \mathrm{v}) \mathrm{MgCl}_{2}$ (containing $\mathrm{l}^{-1}$ : $10 \mathrm{~g}$ starch, $0.3 \mathrm{~g}$ casein, $2 \mathrm{~g} \mathrm{KNO}, 0.05 \mathrm{~g} \mathrm{MgSO}_{4} \cdot 7 \mathrm{H}_{2} \mathrm{O}, 2 \mathrm{~g}$ $\mathrm{NaCl}, 2 \mathrm{~g} \mathrm{~K}_{2} \mathrm{HPO}_{4}, 0.02 \mathrm{~g} \mathrm{CaCO}_{3}, 200 \mathrm{~g} \mathrm{MgCl}_{2} .6 \mathrm{H}_{2} \mathrm{O}$, $20 \mathrm{~g}$ agar; $\mathrm{pH}$ 7.2). The isolate was stored in $20 \%$ glycerol at $-20{ }^{\circ} \mathrm{C}$.

For observations of the sporophores, spore chains and spore surfaces, strain YIM $90018^{\mathrm{T}}$ was cultivated on YIM 82 agar [containing $\mathrm{l}^{-1}: 5 \mathrm{~g}$ starch, $1 \mathrm{~g}$ asparagine, $1 \mathrm{~g} \mathrm{~K}_{2} \mathrm{HPO}_{4}$, $3.7 \mathrm{mg}$ vitamin mixture from $\mathrm{HV}$ agar (Hayakawa \& Nonomura, 1987), $1 \mathrm{ml}$ trace salts from International Streptomyces Project (ISP) medium 5 (Shirling \& Gottlieb, 1966), 20 g agar; $\mathrm{pH} 7.2$ or $\mathrm{pH}$ 10.0-11.0] and examined by light and scanning electron microscopy (JSM-5600LV, JEOL). Cultural characteristics were studied on ISP media (Shirling \& Gottlieb, 1966), Czapek's agar, nutrient agar (Waksman, 1961), YIM 81 agar (containing $1^{-1}: 1 \mathrm{~g}$

Abbreviation: ISP, International Streptomyces Project.

The GenBank/EMBL/DDBJ accession number for the 16S rRNA gene sequence of strain YIM $90018^{\top}$ is AJ849545. asparagine, $10 \mathrm{~g}$ glycerol, $0.5 \mathrm{~g}$ yeast extract, $0.5 \mathrm{~g} \mathrm{KNO}_{3}$, $1 \mathrm{~g} \mathrm{~K}_{2} \mathrm{HPO}_{4}, 20$ g agar; $\mathrm{pH} 7.2$ or $\mathrm{pH} 10-11$ ) and YIM 82 agar after incubation for 14 days at $28{ }^{\circ} \mathrm{C}$. The colour of both substrate and aerial mycelia, together with the production of soluble pigments, was determined by comparison with chips from the ISCC-NBS colour charts (Kelly, 1964). All tests were done at $28{ }^{\circ} \mathrm{C}$ and pH 7.2 unless otherwise specified. The production of melanin was tested on ISP 7. Carbon source utilization was examined using ISP 9 as the basal medium supplemented with $1 \%$ final concentration of the tested substrate. Nitrogen source utilization, catalase production and starch and gelatin degradation were detected in modified Bennett agar after 7, 14 and 21 days, as described by Williams et al. (1983). Hydrogen sulphide production was detected by the method of Shirling \& Gottlieb (1966). The effect of temperature, $\mathrm{pH}$ and salts on growth was determined using modified Bennett agar as the basal medium.

For chemotaxonomic studies, strain YIM $90018^{\mathrm{T}}$ was grown in potato extract-glucose broth $(200 \mathrm{~g}$ fresh potato boiled in 11 water for $30 \mathrm{~min}$ and filtered) on a shaking incubator at 200 r.p.m. at $28{ }^{\circ} \mathrm{C}$ for 7 days. Mycelium was harvested by centrifugation, washed three times with distilled water and then freeze-dried. The determination of diamino acid in the cell wall and the analysis of the whole-cell sugars were performed as described by Lechevalier \& Lechevalier $(1970,1980)$ and Staneck \& Roberts (1974), respectively. Polar lipids were extracted 


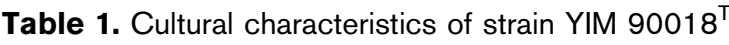

Colours are according to ISCC-NBS colour charts, standard sample no. 2106 (Kelly, 1964). + + +, Good; ++ , moderate; + , weak; - , none. No growth took place on glucose-asparagine agar.

\begin{tabular}{|lccccccc|}
\hline \multirow{2}{*}{ Medium } & \multicolumn{2}{c}{ Aerial mycelium } & & \multicolumn{2}{c|}{ Substrate mycelium } \\
\cline { 2 - 3 } \cline { 6 - 7 } & Growth & Colour & & Growth & Colour \\
\hline Czapek's agar & - & - & & + & - \\
Glycerol-asparagine agar (ISP 5) & - & - & & & + & Brilliant yellow \\
Inorganic salt-starch agar (ISP 4) & - & & - & & ++ & Light yellow \\
Yeast extract-malt extract agar (ISP 2) & - & & - & & ++ & Brilliant yellow \\
Potato extract agar & - & & - & & +++ & Brilliant yellow \\
Nutrient agar & - & & - & & ++ & Brilliant yellow \\
YIM 81 agar & - & & - & & ++ & Light yellow \\
YIM 82 agar & & & & Pale grey & & + & Pale yellow \\
\hline
\end{tabular}

and detected by the method of Komagata \& Suzuki (1987). Menaquinones were extracted, purified and identified by HPLC as described by Collins (1985). The cellular fatty acid composition was analysed as described by Sasser (1990). The DNA G $+\mathrm{C}$ base content was determined by HPLC (Tamaoka \& Komagata, 1984) using an Agilent 1100 LC system (IRIS Technologies). DNA-DNA hybridization between strain YIM $90018^{\mathrm{T}}$ and its closest phylogenetic neighbours was carried out as described by Christensen et al. (2000).

For 16S rRNA gene sequence analysis, genomic DNA was extracted by the method described by Orsini \& RomanoSpica (2001). PCR-mediated amplification of the $16 \mathrm{~S}$ rRNA gene, purification of the PCR products and sequence analysis of the purified products were performed as described by Cui et al. (2001). The resultant sequence was manually aligned against bacterial sequences available from public databases. A more detailed comparison was performed with sequences from members of the genus Streptomyces and evolutionary distance matrices were calculated by the method of Jukes \& Cantor (1969).
Phylogenetic trees were inferred by using the neighbourjoining (Saitou \& Nei, 1987) and maximum-likelihood (Felsenstein, 1981) methods. Bootstrap analysis (Felsenstein, 1985) with 1000 resamplings was used to evaluate the topology of the neighbour-joining tree.

The cultural and morphological characteristics of strain YIM $90018^{\mathrm{T}}$ are shown in Tables 1 and 2, respectively. Observation of 15-day-old cultures revealed that strain YIM $90018^{\mathrm{T}}$ produced a poor, pale grey, aerial mycelium on YIM 82 agar but did not produce aerial hyphae on the other media tested. Vegetative hyphae were abundant, not fragmented and light or brilliant yellow. Straight to flexuous (rectiflexibiles) spore chains were only present on YIM 82 agar. Spores were short and rod-shaped and variable in size $(0.5-0.7 \times 1.0-1.3 \mu \mathrm{m})$. The spore surface was smooth (Fig. 1). Soluble pigments were not produced on any media.

The 16S rRNA gene sequence (1466 nt) of strain YIM $90018^{\mathrm{T}}$ was compared with corresponding sequences of type strains of species of the genus Streptomyces. The

Table 2. Comparison of morphological characteristics of strain YIM $90018^{\top}$ and some members of the genus Streptomyces

Strains: 1, YIM $90018^{\mathrm{T}}$ (data from this study); 2, S. rimosus subsp. rimosus (Yan, 1992); 3, S. sclerotialus (Yan, 1992); 4, S. niger (Yan, 1992); 5, S. erumpens (Yan, 1992); 6, S. kasugaensis (Yan, 1992; Backus \& Tresner, 1956); 7, S. olivaceiscleroticus (Yan, 1992). ND, No data available.

\begin{tabular}{|c|c|c|c|c|c|c|c|}
\hline Characteristic & 1 & 2 & 3 & 4 & 5 & 6 & 7 \\
\hline Aerial hyphae & Sparse, pale grey & $\begin{array}{c}\text { Abundant, white, } \\
\text { yellow }\end{array}$ & $\begin{array}{l}\text { Abundant, sclerotia, } \\
\text { white, yellowish red, } \\
\text { pale yellow-green }\end{array}$ & $\begin{array}{l}\text { Abundant, } \\
\text { grey }\end{array}$ & $\begin{array}{l}\text { Abundant, } \\
\text { grey }\end{array}$ & $\begin{array}{l}\text { Abundant, } \\
\text { white }\end{array}$ & $\begin{array}{l}\text { Abundant, } \\
\text { pale white, } \\
\text { grey-black }\end{array}$ \\
\hline Spore chain & $\begin{array}{l}\text { Straight to flexuous } \\
\text { (rectiflexibiles) }\end{array}$ & Spiral & Spiral & Spiral & Spiral & $\begin{array}{l}\text { Loops and } \\
\text { spiral }\end{array}$ & Spiral \\
\hline Spore shape & Short rod & Oval & Oval & Oval & $\mathrm{ND}$ & ND & Oval \\
\hline Substrate hyphae & Yellow & $\begin{array}{l}\text { Brown, } \\
\text { red-brown }\end{array}$ & $\begin{array}{c}\text { Orange-yellow, green, } \\
\text { yellowish brown }\end{array}$ & Black & Brown & $\begin{array}{l}\text { Brown, red- } \\
\text { brown }\end{array}$ & Black, brown \\
\hline Diffusible pigments & None & $\begin{array}{c}\text { Yellow, yellowish } \\
\text { brown }\end{array}$ & $\begin{array}{l}\text { Yellowish brown, } \\
\text { green }\end{array}$ & Brown & Yellow & $\begin{array}{c}\text { Dark yellow, } \\
\text { yellowish } \\
\text { brown }\end{array}$ & $\begin{array}{c}\text { Olive yellow, } \\
\text { pale red }\end{array}$ \\
\hline
\end{tabular}




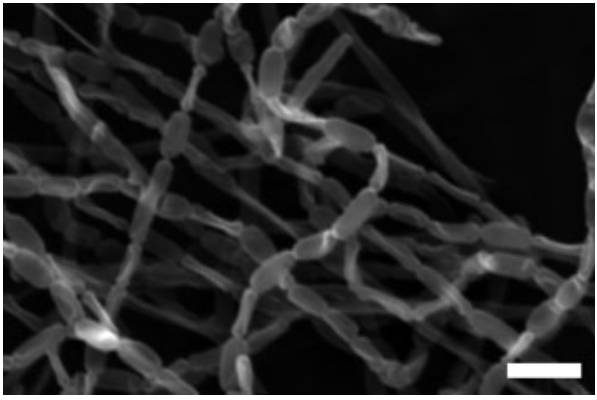

Fig. 1. Scanning electron micrograph showing spores and spore chains of strain YIM $90018^{\top}$ after growth on YIM 82 agar at $28^{\circ} \mathrm{C}$ for 15 days. Bar, $2 \mu \mathrm{m}$.

neighbour-joining tree based on 16S rRNA gene sequences is shown in Fig. 2. The phylogenetic analysis revealed that strain YIM $90018^{\mathrm{T}}$ was phylogenetically related to the genus Streptomyces and formed a separate clade. The highest sequence similarities were found with Streptomyces rimosus subsp. rimosus JCM $4667^{\mathrm{T}}$ (98.55\% $16 \mathrm{~S}$ rRNA gene sequence similarity), $S$. erumpens DSM $40941^{\mathrm{T}}$ (98.33\%), S. sclerotialus DSM $43032^{\mathrm{T}}$ (98.04\%), S. olivaceiscleroticus DSM $40595^{\mathrm{T}}(97.99 \%)$, S. niger DSM $43049^{\mathrm{T}}(97.99 \%)$ and S. kasugaensis NBRC $13851^{\mathrm{T}}$ (97.6\%).

The fatty acid content of strain YIM $90018^{\mathrm{T}}$ was remarkably different from related members of the genus
Streptomyces (Table 3). Strain YIM $90018^{\mathrm{T}}$ contained $38.1 \% \quad \mathrm{C}_{18: 1} \omega 9 c$, of which $S$. sclerotialus DSM $43032^{\mathrm{T}}$ contained $0.7 \%$ and S. kasugaensis DSM $40819^{\mathrm{T}}$ and $S$. niger DSM $43049^{\mathrm{T}}$ contained none. Strain YIM $90018^{\mathrm{T}}$ also contained $\mathrm{C}_{16: 1} \omega 9 c$ and $\mathrm{C}_{20: 1} \omega 9 c$, which were not found in the reference strains. The reference strains contained $25.7-34.0 \%$ anteiso- $C_{15: 0}$, of which strain YIM $90018^{\mathrm{T}}$ contained only $6.6 \%$, and $4.2-12.0 \%$ iso- $\mathrm{C}_{17: 0}$, of which strain YIM $90018^{\mathrm{T}}$ contained none. DNA-DNA relatedness between strain YIM $90018^{\mathrm{T}}$ and its closest phylogenetic neighbours was $<60 \%$ (Fig. 3).

The physiological and biochemical characteristics, utilization of carbon and nitrogen sources, chemotaxonomic characteristics and antimicrobial activities of strain YIM $90018^{\mathrm{T}}$ are given in the species description. In contrast to some of its closest phylogenetic neighbours, strain YIM $90018^{\mathrm{T}}$ was negative for pigment production and gelatin liquefaction and positive for milk coagulation and peptonization and antimicrobial activity. S. sclerotialus and S. niger, which have been merged into S. phaeochromogenes (Locci, 1989; Skerman et al., 1980; Yan, 1992), are positive for pigment production and gelatin liquefaction and negative for milk coagulation and peptonization and antimicrobial activity; $S$. kasugaensis is positive for pigment production and gelatin liquefaction and negative for milk coagulation.

The diagnostic properties of strain YIM $90018^{\mathrm{T}}$ were the absence of aerial mycelium and soluble pigment, flexuous spore chains (rectiflexibiles), short rod-shaped spores, growth with $25 \% \mathrm{MgCl}_{2} \cdot 6 \mathrm{H}_{2} \mathrm{O}$ and $\mathrm{C}_{18: 1} \omega 9 \mathrm{c}$ as the

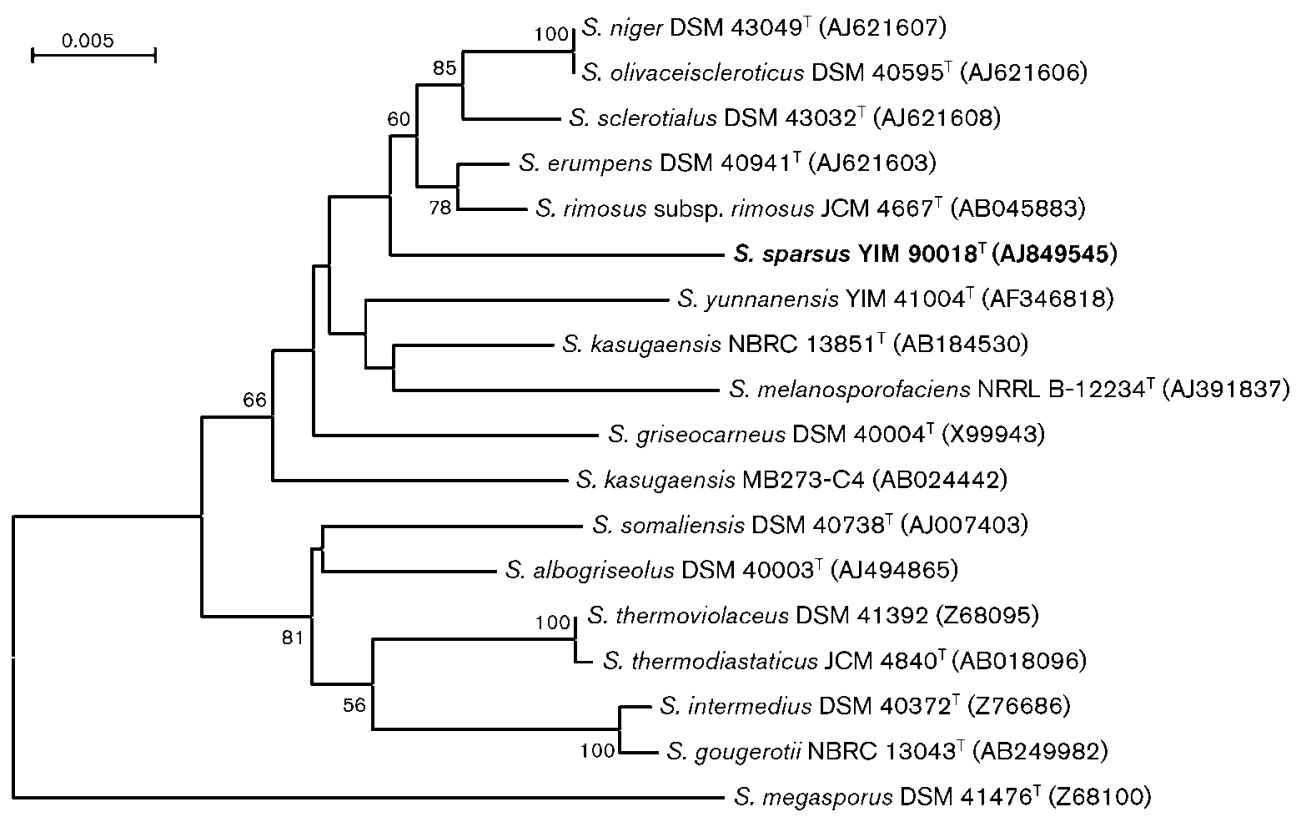

Fig. 2. Phylogenetic dendrogram obtained by distance matrix analysis of $16 \mathrm{~S}$ rRNA gene sequences showing the position of strain YIM $90018^{\top}$ among its phylogenetic neighbours. Bootstrap values ( $>50 \%$ ) based on 1000 resamplings are shown at branch nodes. Streptomyces megasporus DSM $41476^{\top}$ was used as an outgroup. Bar, $0.5 \%$ sequence divergence. 
Table 3. Comparison of fatty acids of strain YIM $90018^{\top}$ with related members of the genus Streptomyces

Strains: 1, YIM $90018^{\mathrm{T}}$; 2, S. kasugaensis DSM 40819 ${ }^{\mathrm{T}}$; 3, S. sclerotialus DSM 43032 ${ }^{\mathrm{T}}$; 4, S. niger DSM $43049^{\mathrm{T}}$.

All data were taken from this study.

\begin{tabular}{|c|c|c|c|c|}
\hline Fatty acid (\%) & 1 & 2 & 3 & 4 \\
\hline iso- $\mathrm{C}_{13: 0}$ & - & - & - & 0.6 \\
\hline anteiso- $\mathrm{C}_{13: 0}$ & - & - & 0.3 & 0.6 \\
\hline iso- $\mathrm{C}_{14: 0}$ & 1.2 & 5.2 & 2.8 & 4.2 \\
\hline $\mathrm{C}_{14: 0}$ & 0.9 & - & 0.4 & 0.8 \\
\hline iso- $\mathrm{C}_{15: 0}$ & 2.0 & 17.6 & 7.4 & 13.0 \\
\hline anteiso- $\mathrm{C}_{15: 0}$ & 6.6 & 25.7 & 34.0 & 31.5 \\
\hline $\mathrm{C}_{15: 0}$ & - & 1.0 & 1.7 & 1.9 \\
\hline iso- $\mathrm{C}_{16: 0}$ & 16.0 & 8.9 & 14.8 & 13.3 \\
\hline anteiso- $\mathrm{C}_{16: 0}$ & 1.4 & - & - & - \\
\hline $\mathrm{C}_{16: 0}$ & 14.4 & 19.1 & 5.9 & 10.0 \\
\hline iso- $\mathrm{C}_{16: 1} \mathrm{H}$ & 4.0 & - & 0.8 & - \\
\hline $\mathrm{C}_{16: 1} \omega 9 c$ & 1.1 & - & - & - \\
\hline iso- $\mathrm{C}_{17: 0}$ & - & 12.0 & 4.2 & 6.8 \\
\hline anteiso- $\mathrm{C}_{17: 0}$ & 4.8 & 8.1 & 17.7 & 13.5 \\
\hline $\mathrm{C}_{17: 0}$ cyclo & - & - & - & 0.5 \\
\hline$C_{17: 0}$ & - & - & 0.9 & 1.1 \\
\hline $\mathrm{C}_{18: 1} \omega 9 c$ & 38.1 & - & 0.7 & - \\
\hline $\mathrm{C}_{20: 1} \omega 9 c$ & 1.5 & - & - & - \\
\hline
\end{tabular}

major fatty acid. Therefore, a novel species of the genus Streptomyces, with the name Streptomyces sparsus sp. nov., is proposed to accommodate strain YIM $90018^{\mathrm{T}}$.

\section{Description of Streptomyces sparsus sp. nov.}

Streptomyces sparsus [spar'sus. L. masc. part. adj. sparsus (from L. v. spargo) scattered, sparse; referring to a streptomycete with sparse aerial mycelium].

No aerial hyphae are formed on most media tested, but extremely poor and pale grey aerial mycelium is formed on YIM 82 agar. Yellowish vegetative hyphae grow well and do not fragment. Soluble pigments are not formed. Straight to flexuous (rectiflexibiles) spore chains are produced. Spores are short and rod-shaped with smooth surfaces. Positive for milk coagulation and peptonization, growth on cellulose and production of $\mathrm{H}_{2} \mathrm{~S}$. Negative for gelatin liquefaction, starch hydrolysis, nitrate reduction and melanin formation. Grows with $0-15 \% \mathrm{NaCl}, 0-5 \%$
$\mathrm{KCl}, 0-25 \% \mathrm{MgCl}_{2} \cdot 6 \mathrm{H}_{2} \mathrm{O}$ and $0-1 \% \mathrm{CaCl}_{2}$ and at pH 6.0-10.0. Utilizes glucose, galactose, rhamnose, arabinose, xylose, raffinose, starch, ribose, inositol, mannitol, glycine, histidine, methionine and asparagine, but not sorbitol. Acid is produced from glucose. Has antimicrobial activity against Bacillus subtilis (ACCC 11060), Staphylococcus aureus (AS 1.72), Micrococcus luteus (ACCC 11001), 'Sarcina lutea' (AS 1.241) and Xanthomonas oryzae (AS 1.843). The cell-wall peptidoglycan contains LL-diaminopimelic acid and glycine. The whole-cell hydrolysate contains galactose and xylose. The predominant menaquinones are MK-9 $\left(\mathrm{H}_{4}\right)(48 \%)$, MK$9\left(\mathrm{H}_{6}\right) \quad(39 \%)$ and MK-9 $\left(\mathrm{H}_{8}\right) \quad(13 \%)$. The diagnostic phospholipid is phosphatidylethanolamine. The major fatty acids $(>5 \%)$ are $\mathrm{C}_{18: 1} \omega 9 c$, iso- $\mathrm{C}_{16: 0}, \mathrm{C}_{16: 0}$ and anteiso- $\mathrm{C}_{15: 0}$.

The type strain, YIM $90018^{\mathrm{T}}\left(=\right.$ CCTCC AA204019 ${ }^{\mathrm{T}}=$ DSM $41858^{\mathrm{T}}$ ), was isolated from a saline and alkaline soil sample

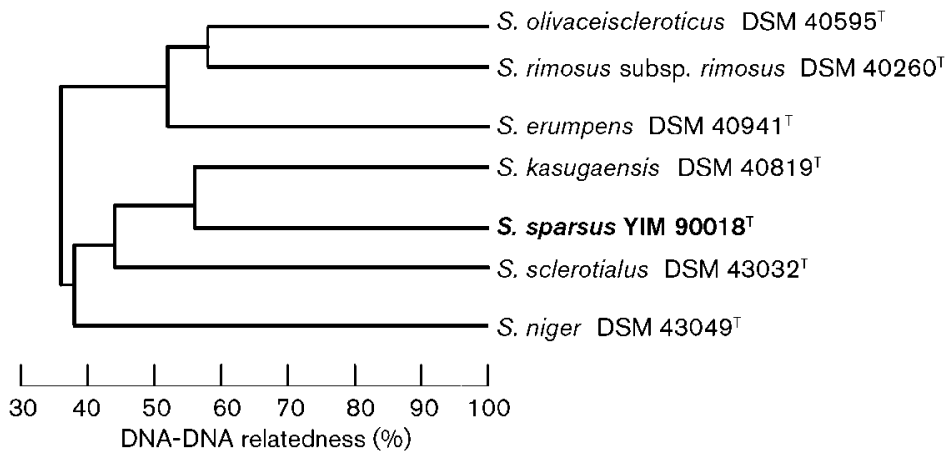

Fig. 3. DNA-DNA relatedness between strain YIM $90018^{\top}$ and its closest phylogenetic neighbours. 
collected from Qinghai Province, China. The DNA G + C content of the type strain is $71.2 \mathrm{~mol} \%$.

\section{Acknowledgements}

This research was supported by the National Natural Science Foundation of China (grant numbers 30900002 and 30560001), the International Cooperative Key Project of Ministry of Science and Technology (grant number 2006DFA33550) and Talents in University and the 'Zentrum für Marine Wirkstoffe', which is funded by the Ministerium für Wirtschaft, Wissenschaft und Verkehr des Landes Schleswig-Holstein (Germany). We thank X.-F. Cai and Y. Chen for their technical assistance.

\section{References}

Backus, E. J. \& Tresner, H. D. (1956). A broadened concept of the characteristics of Streptomyces hygroscopicus. Appl Microbiol 4, 243250.

Christensen, H., Angen, O., Mutters, R., Olsen, J. E. \& Bisgaard, M. (2000). DNA-DNA hybridization determined in micro-wells using covalent attachment of DNA. Int J Syst Evol Microbiol 50, 10951102.

Collins, M. D. (1985). Isoprenoid quinone analysis in bacterial classification and identification. In Chemical Methods in Bacterial Systematics, pp. 267-287. Edited by M. Goodfellow \& D. E. Minnikin. London: Academic Press.

Cui, X. L., Mao, P. H., Zeng, M., Li, W. J., Zhang, L. P., Xu, L. H. \& Jiang, C. L. (2001). Streptimonospora salina gen. nov., sp. nov., a new member of the family Nocardiopsaceae. Int J Syst Evol Microbiol 51, 357-363.

Felsenstein, J. (1981). Evolutionary trees from DNA sequences: a maximum likelihood approach. J Mol Evol 17, 368-376.

Felsenstein, J. (1985). Confidence limits on phylogenies: an approach using the bootstrap. Evolution 39, 783-791.

Hayakawa, M. \& Nonomura, H. (1987). Humic acid-vitamin agar, a new medium for the selective isolation of soil actinomycetes. J Ferment Technol 65, 501-509.

Jukes, T. H. \& Cantor, C. R. (1969). Evolution of protein molecules. In Mammalian Protein Metabolism, pp. 21-132. Edited by H. N. Munro. New York: Academic Press.
Kelly, K. L. (1964). Inter-Society Color Council - National Bureau of Standards Color Name Charts Illustrated with Centroid Colors. Washington, DC: US Government Printing Office.

Komagata, K. \& Suzuki, K. (1987). Lipid and cell-wall analysis in bacterial systematics. Methods Microbiol 19, 161-207.

Lechevalier, M. P. \& Lechevalier, H. A. (1970). Chemical composition as a criterion in the classification of aerobic actinomycetes. Int J Syst Bacteriol 20, 435-443.

Lechevalier, M. P. \& Lechevalier, H. A. (1980). The chemotaxonomy of actinomycetes. In Actinomycete Taxonomy, pp. 227-291. Edited by A. Dietz \& D. W. Thayer. Arlington, VA: Society for Industrial Microbiology.

Locci, R. (1989). Streptomyces and related genera. In Bergey's Manual of Systematic Bacteriology, vol. 4, pp. 24-77. Baltimore: Williams \& Wilkins.

Orsini, M. \& Romano-Spica, V. A. (2001). A microwave-based method for nucleic acid isolation from environmental samples. Lett Appl Microbiol 33, 17-20.

Saitou, N. \& Nei, M. (1987). The neighbor-joining method: a new method for reconstructing phylogenetic trees. Mol Biol Evol 4, 406-425.

Sasser, M. (1990). Identification of bacteria by gas chromatography of cellular fatty acids. USFCC Newsl 20, 16.

Shirling, E. B. \& Gottlieb, D. (1966). Methods for characterization of Streptomyces species. Int J Syst Bacteriol 16, 313-340.

Skerman, V. B., Mcgowan, D. V. \& Sneath, P. H. A. (1980). Approved lists of bacterial names. Int J Syst Bacteriol 30, 225-420.

Staneck, J. L. \& Roberts, G. D. (1974). Simplified approach to identification of aerobic actinomycetes by thin-layer chromatography. Appl Microbiol 28, 226-231.

Tamaoka, J. \& Komagata, K. (1984). Determination of DNA base composition by reversed-phase high-performance liquid chromatography. FEMS Microbiol Lett 25, 125-128.

Waksman, S. A. (1961). The Actinomycetes, Classification, Identification and Description of Genera and Species, vol. 2. Baltimore: Williams \& Wilkins.

Waksman, S. A. \& Henrici, A. T. (1943). The nomenclature and classification of the actinomycetes. J Bacteriol 46, 337-341.

Williams, S. T., Goodfellow, M., Alderson, G., Wellington, E. M. H., Sneath, P. H. A. \& Sackin, M. J. (1983). Numerical classification of Streptomyces and related genera. J Gen Microbiol 129, 1743-1813.

Yan, X. C. (1992). Classification and Identification of Actinomycetes. Beijing: Academic Press. 